\title{
SEX DIFFERENCES IN GENETIC MECHANISMS FOR MAMMALIAN BRAIN AND BEHAVIOR
}

\author{
Stephen C.Maxson \\ Biobehavioral Sciences Graduate Degree Program, Department of Psychology, University of Connecticut, \\ Storrs, Connecticut, USA
}

\section{SUMMARY}

- There are sex specific genetic mechanisms for mammalian brain and behavior. These are genes that act differently in each sex. They may underlie either similarities or differences in brain and behavior of males andfernales. Some of these genes are autosomal. Others are located on the non-recombining part of the $Y$ chromosome. Genes on this region of the $Y$ chromosome may contribute to sex differences in brain and behavior in three ways. First, a gene may be on the Y chromosome and not on any other chromosome. Thus, it acts only in males. Sex-determining region on the $Y$ chromosome (Sry) is such a gene. Second, there may be different isoforms of proteins coded for by the gene on the $Y$ chromosome and by its homologue located elsewhere in the genome. Such a gene is Smcy which codes for an H-Yantigen. Smcx is its X-chromosomal homologue. Third, there may be different protein levels in males and females for a gene located on the $X$ and $Y$ chromosomes. Zfy and $Z f x$, for the zinc finger proteins on the $Y$ and on the $X$, are a pair of such genes. Due to $X$ inactivation in females, one copy of $Z f x$ is expressed in all tissues of female mice, whereas two copies, one of Zfx and one of Zfy, are expressed in many tissues of male mice. (Biomed Rev 1997; 7: 85-90)

Received for publication 17 April 1997 and accepted 30 June 1997. Correspondence and reprint requests to Dr Stephen C. Maxson, Biobehavioral Sciences, U-154, 3107 Horse Barn Hill Road, University of Connecticut, Storrs, CT 06269-4154, USA.

Tel: 1 (860) 486 2455, Fax: 1 (860)4863827,

E-mail: smaxson@uconnvm.uconn.edu

\section{INTRODUCTION}

There are sex specific genetic mechanisms for mammalian brain and behavior. These are genes that have different effects in each sex, and may cause phenotypic similarities or differences between the sexes. Here, I will briefly describe autosomal genes which may be sex specific. The rest of the review will focus on genes of the non-recombining part of the Y chromosome of placental mammals, especially mice, which are obviously sex specific.

\section{AUTOSOMES}

- Crossbreeding of inbred strains of mice is being used to identify genes, known as quantitative trait loci (QTL), with effects on complex traits, such as brain and behavior $(1,2)$. The chromosomal positions in $\mathrm{cM}$ of genes with effects on trait variation are identified in relation to known markers and genes. These genes may be identified at the molecular level by positional candidates (1) or positional cloning (3). It has been proposed that there are sex specific QTL for hypertension in rats (4), nociception in mice (5), stress-induced analgesia (5), and alcohol preference (6). The Alcpl gene on chromosome 2, for example, appears to cause variation in alcohol preference of male but not female mice, whereas the Alcp2 gene on chromosome 11 appears to cause variation in alcohol preference of female but not male mice. There are many methodological issues that must be considered in firmly establishing findings on QTL (reviewed in 7-9).

Transgenic mice, including knockout mutants, are also being 
used to identify genes with effects on complex traits, such as brain and behavior (10). Such genes have already been characterized at the molecular level and their chromosomal position is frequently known. Using knockouts, there appears to be sex specific genes with effects on copulalory, aggressive, and open field behaviors of mice. Knockout mutants for the 5-hydroxylryptamine $\left(5-\mathrm{HT}^{\wedge}\right)$ receptor $(11)$, monoamine oxidase A (MAOAX 12), and nitric oxide synthase 1 (NOS-1)( 13) affect male but not female copulatory behaviors. The null mutant for Htrlb in males decreases the latency to copulation and increases the frequency of mounting. Also, the null mutants of MAO-A and NOS-1 display abnormal sexual behavior with non-estrous females. Similarly, mutants for cstrogen receptor $(\mathrm{ER})(14,15)$, MAO-A, NOS-1, and transforming growth factor-a (TGF-a) (16, 17) have differential effects on male and female aggression. The null mutant for NOS-1 decreases latency and increases frequency of attacks in males but not females, and that for MAOA decrease latency to attack and increase amount of wounding in males but not females. In contrast, the null mutant for ER1 decreases attack duration of male mice paired with male opponents and increases attack duration of female mice paired with female opponents. Similarly, a variant for TGF-a increases aggressive behaviors in males but decreases aggressive behaviors in females. Also, the null mutant for ER decreases open field activity in male but increases it in female mice. There are many methodological issues that must he considered in firmly establishing findings with knockouts and other transgenics (reviewed in 18).

\section{YCHROMOSOME}

M Genes on the non-rccombining part of the $\mathrm{Y}$ chromosome arc transmitted normally from father to son, and they obviously act and cause variation in males but not females. About 10 genes have been identified on the non-recombining region of the mouse Y chromosome, and about 30 genes have been identified on the non-recombining region of the human $\mathrm{Y}$ chromosome $(19,20)$.Also, there may be an additional 100 to 500 genes on the Y chromosome of mice, humans, and other placental mammals (21). In spite of arguments to the contrary (22), these genes may have an influence not only on variation among male, but also on differences between male and female mammals in brain and behavior.

There arc Y chromosome effects on brain and behavior of male mice. They include effects on hippocampal weight (23), asymmetry in hippocampal size (23), hippocampal mossy fiber distribution (24), whole brain levels of serotonin (25) and dynorphin (26), open Held behavior (27), circadian rhythms (28), coping strategies (29), apomorphinc-induced stereotypy (30), copulatory behaviors $(31,32)$, aggressive behavior (33-35), and discrimination learning (23). Reciprocal Fls, segregating populations, and congenic strains have been used in these studies.
Elsewhere, I have reviewed methodological issues in using these breeding systems to show effects of the non-recombining region of the $\mathrm{Y}$ chromosome on traits of male mice (36).

Sex differences have been shown in voles for hippocampal size (37), in rats for hypothalamic and whole brain serotonin levels $(38,39)$, in rodents for regional and whole brain ncuropeptide levels (40), and in mice for open field $(11,12)$, copulatory $(41,42)$ and aggressive behaviors $(11,12,43)$. Since there are $\mathrm{Y}$ chromosomal effects in mice on these brain or behavior traits, it is conceivable that genes on the non-recombining region of the $\mathrm{Y}$ chromosome by acting in males and not females could contribute at least to these sex differences. A role for the Y chromosome in behavioral sex differences has been suggested (44). A gene, F/p, on the Y chromosome, for example, has been proposed for channel flipping in males and not females. A more serious proposal is made here for three genetic mechanisms involving genes on the $\mathrm{Y}$ chromosome of male mice that could account for sex differences in brain and behavior.

A gene on the non-recombining part of the $\mathrm{Y}$ chromosome and nowhere else in the genome might have a role in sex differences. There is one such gene on the mammalian Y chromosome. In mice, this is .Sry gene which codes for a high mobility group (HMG) transcription factor (45). This gene is essential for differentiation of the primordial gonad into a testis (46). It is also expressed in brains of marsupials (47), mice (48), and humans (49). The transcript in adult mouse brain is linear and is capable of being translated. Sry protein may bind to five response elements in target genes contributing to activation of their transcription. The Sry protein binds to response elements in the geneFraJ and regulates expression of Fral (50). Fral is a component of activator protein-1 transcription factors which regulate many genes including those coding for neuropeptides (51). Alternatively, Sry may compete with the transcription factors Soxl, 2 or 3 for response elements of target genes and thereby block or attenuate the activation of transcription by Sox 1,2 or 3 (52). Sox 1,2 and 3 are expressed in brain (53). Either of these mechanisms may have a role not only in effects of the non-recombining part of the Y chromosome on brain and behaviors of males, but also of sex differences in brain and behavior.

A gene on the Y chromosome may code for a different isoform of a protein than that coded for by its homologue elsewhere in the genome. An example of this is the gene pair J'mcy andS'mcx in mice. These are transcribed in all tissues including brain. They code for zinc finger transcription factors, and peptides derived from them are minor histocompatibility antigens $(54,55)$. The Xand Y-chromosomal peptides of their antigens differ in five amino acids. There is a second pair of such antigens (UTX and UTY) on the mouse $\mathrm{X}$ and $\mathrm{Y}$ chromosomes. They differ by three amino acids (56). The genes are transcribed in many tissues including 
brain, and their proteins may also be transcription factors. Rps4y and Rps $4 x$ arc another example of genes on the human $\mathrm{X}$ and $\mathrm{Y}$ chromosomes coding for different isoforms of the same protein (57). Here, there are 19 amino acid differences for a small ribosomal protein. These genes are transcribed in many tissues including brain. Also, this gene is in an area of the human Y implicated in Turner's syndrome. Such differences between males and females in isoforms may contribute to sex differences in brain and behavior.

In placenta! mammals, most but not all genes on one of the $\mathrm{X}$ chromosomes of females are inactivated at random in each cell. For these genes, one copy is expressed in all female cells. There are $\mathrm{X}$ chromosomal homologues for many $\mathrm{Y}$ chromosomal genes of placental mammals (58). Both the $\mathrm{X}$ and $\mathrm{Y}$ chromosomal genes are expressed in males, or in other words, two copies arc expressed in some, if not all, male cells. An example of ihis is the pair of mouse genes $Z f x$ and $Z f y$ (59). These are respectively zinc finger on the $\mathrm{X}$ and on the $Y . Z f x$ is expressed in all cells of males and females, whileZ/y is expressed in some bul not all cells of females. It is not expressed in neurons (60). Another example of this dose difference between males and females is for the genes Amelx and Amely (61); for amelogenin of the $\mathrm{X}$ and $\mathrm{Y}$, respectively. Amelogenin is a tooth enamel protein. Because of the difference in dose of gene expression in males and females in ameloblasts of tooth buds, males have about $10 \%$ more amelogenin then females and may thereby have larger teeth than females (62). There may also be similar dose effect differences for developmental rate or growth factor genes located on the $\mathrm{X}$ and $\mathrm{Y}$ chromosomes (63-65).

There is recent direct evidence for effects of the $\mathrm{Y}$ chromosome on sex differences in behavior. On the C57BL6 background, mice with the $\mathrm{Y}$ chromosome from posciavinus are either $\mathrm{XY}$ males or XY females (66). The XY females have ovaries or ovatestes. XX females, XY females (ovaries), and XY males on the C57BL6 background have been tested for open field activity, active avoidance, water escape, and Morris maze learning (67). The XX females and XY males differ on each of these behaviors. XY females resemble XX females for open field behavior, active avoidance, and water escape, and XY females resemble XY males for Morris maze learning. These findings arc consistent with the hypothesis that sex differences in open field behavior, active avoidance, and water escape are due to differences in gonadal hormones of males and females, and that the sex difference in Morris maze learning is due to a hormoneindependent effect of one or more Y chromosomal genes. It remains to be determined whether other Y chromosomal effects on male brain and behavior and on sex differences in brain and behavior are hormonally dependent or independent. There is at least one gene on the mouse $\mathrm{Y}$ chromosome with effects on adult serum levels of testosterone and at least one other gene with effects on target organ sensitivity to testosterone (68).

\section{CONCLUSION}

- It has been proposed that there are hormonal and nonhormonal mechanisms for the development of sex differences in mammalian brain and behavior (69,70). Genes, including those of the Y chromosome, are involved in both mechanisms. Sry, for example, is involved in determining whether or not the gonad develops as a testis or ovary and thereby the hormonal environment of male or female. These hormones of males and females are involved in sex-specific expression of genes. Some genes described in the section on autosomes may be sex-specific because of effects of sex-specific hormonal environments of males and females. Further research is needed to determine which genes these are. Alternatively, Sry may have direct effects on sex differences in brain and behavior which do not involve differences between males and females in hormonal environments. Since Sry is a transcription factor, some of the genes described in the Section on Autosomes may be sex specific because their expression is regulated by Sry in males but not in females. Again, further research is necessitated to define which autosomal genes these are. Such research will contribute to our understanding of the genetic bases for hormonally dependent and independent sex differences in mammalian brain and behavior.

\section{REFERENCES}

1. Crabbe JC, Bel knap JK, Buck KJ. Genetic animal models of alcohol and drug abuse. Science 1994; 264: 1715-1723

2. Frankel WN. Taking stock of complex trait genetics in mice. Trends Genet 1995; 11:471 -476

3. Nelson DL. Positional cloning reaches maturity. Curr Opin Genet Dev 1995; 5:298-303

4. Jacob H. Complex traits and the rat genetic map. Workshop on the Biology and Genetics of Complex Mammalian Traits. The Jackson Laboratory, Bar Harbor, September 1317,1995

5. Mogil JS, Richards SP, Helms ML, O'TooleLA, Belknap JK. Sex-specific quantitative trait loci influencing sensitivity to pain and pain inhibition in mice. Workshop on the Biology and Genetics of Complex Mammalian Traits. The Jackson Laboratory, Bar Harbor, September 13-17,1995

6. Melo JA, Shendure J, PociaskK, Silver LM. Identification of sex-specific quantitative trait loci controlling alcohol preference in C57BL/6 mice. Nat Genet $\backslash 996$; 13: 147-153

7. Belknap JK, Mitchell SR, O'Toole LA, Helms ML, Crabbe JC. Type I and Type II error rates for quantitative trait loci (QTL) mapping studies using recombinant inbred strains. 
Behav Genet $\backslash 996 ; 26$ : 149-160

8. Lander ES, Schrok NS. Genetic dissection of complex traits. Science 1994; 265:2037-2048

9. Lander E, Kruglyak L. Genetic dissection of complex traits: Guidelines for interpreting and reporting linkage results. Nat Genet 1995; 11:241-247

10. Brandon EP, Idzerda RL, McKnight GS. Targeting the mouse genome: A compendium of knockouts (part 1). CurrBiol 1995; 5: 625-634

11. Brunner EB, Holer M, Buhot M-C, Hen R. Do 5-HT. ,, knockout mice display impulsive behavior in food reward choice tusk'? Joe Neumsci Ahstr $\backslash 996 ; 22: 609$

12. Cases O. Scifl, Grimsby.). Gasper P, Chen K, Poumin S et al. Aggressive behavior and altered amounts of brain serotonin and norepinephrine in mice lacking MAO-A. SciEnce 1995;268: 1763-1766

13. Nelson RJ, Deinas GE, Huang PL, Fishman MC, Dawson VL, Dawson TM et al. Behavioral abnormalities in male mice lacking ncuronal nitric oxide synthase. Nature 1995 378:383-386

14. Ogawa S, Taylor .1, Lubahan DB, Korach KS, Pfaff DW. Behavioral masculinization in ERogen receptor gene deficient transgenic female mice. Soc Neurosci Abstr 1996; 22: 698

15. Ogawa S, Lubahan DB. Korach KS, Pfaff DW. Behavioral effects of estrogen receptor gene disruption in male mice. ProcNatlAcadSciUSA 1997; 94: 1476-1481

16. Hilakivi-ClarkcL. Overexpression of transforming growth faclor-cc in transgenic mice alter nonreproductive, sex-related behavioral differences: Interaction with gonadal hormoncK. Behav Neiimxci 1992; 108:410-417

17. Hi laki vi-Clarkc L, Arora PK, Clarkc R, Wright A, Lippman ME. Dickson RB. Opposing behavioral alterations in male and female transgenic TGF-a mice: association with tumor susceptibility. BrJ Cancer $\backslash 993 ;$ 67: 1026-1030

18. Gerlai, R. Gene-targeting studies of mammalian behavior: is it the mutation or the background genotype? Trends Neiimxci\996-19: 177-181

19. Bishop CE, Mitchell MJ. Mouse Y chromosome. Mamm Genome 1996; 6: S331-S333
20. Lau Y-PC, Affara NA. Report of second international workshop on human Y chromosome mapping 1995. Cytogenet Cell Genet 1996; 73: 33-76

21. Affara NA, Lau Y-FC. Report of first international workshop on human Y chromosome mapping 1994. Cytogenet Cell Genet 1994; 67: 359-402

22. Pool R, Eve's Rib. Searching for Biological Roots of Sex Differences. Crown, New York, 1994

23. van Abeelen JHF, Janssens CJJG, Crusio WE, Lemmens WAJG. Y chromosome effects on discrimination learning and hippocampal asymmetry in mice. Behav Genet 1989; 19:543-549

24. Hensbroek RA, Sluyter F, Guillot P-V, van Oortmerssen GA, Crusio WE. Y chromosome effects on hippocampal mossy fiber distributions in mice selected for aggression. Brain Res]995; 682:203-206

25. Tordjman S, Roubertoux PL, Carlier M, Moutier R, Anderson, G, Launay $\mathrm{M}$ etal. Linkage between brain serotonin concentration and sex-specific part of the Y chromosome in mice.NeumsciLett 1995; 183: 190-192

26. Roubertoux PL, Carlier M, Mortaud S, Tordjman S, Degrellc H. Neurobehavioral correlates of the substitution of the specific region of the Y chromosome. Behav Genet 1992; 22:750

27. Monahan E, Maxson SC. Effects of the Y chromosome on open field behaviors in mice. Behav Gene; 1991; 21: 738

28. Sluyter, F. Y chromosome, Aggression, and Coping. PhD Thesis. University of Groningen, The Netherlands, 1994

29. Sluyter F, van Oortmerssen GA, Koolhaas JM. Genetic influences on coping behavior in house mice lines selected for aggression: effects of the Y chromosome. Behaviour 1996:133:117-128

30. Sluyter F, Bohus B, Beldhuis, HJA, van Oortmerssen, GA. Autosomal and Y chromosomal effects on stereotyped response to apomorphine in wild house mice. Phannacol Biochem Behav 1995; 52: 17-22

31. WeirJA, HogleGA. Influence of the Y chromosome on sex ratio and mating behavior in $\mathrm{PHH}$ and $\mathrm{PHL}$ mice. Genetics 1973;74:S294

32. Shrenker P, Maxson SC. The DBA/IBg and DBA/2Bg Y chromosomes compared for their effects on male sexual 
behavior.BehavNeuralBiol 1984;42: 33-37

33. Maxson SC, Didier-Erickson A, Ogawa $S$, The Y chromosome, social signals, and offense in mice. Behav Neural Biol 1989; 52: 251 -259

34. Sluyter F, van Oortmersscn GA, Koolhaas JM. Studies of wild house mice IV: Differential effects of the Y chromosome on intcrmale aggression. Aggress Behav 1994; 20:379386

35. Guillot P-V, Carlier M, Maxson SC, Roubertoux PL. Intcrmale aggression tested in two procedures using four inbred strains of mice and their reciprocal congenics: Ychromosomal implications. Behav Genet 1995; 25: 357360

36. Maxson SC. Methodological issues in genetic analyses of an agonistic behavior (offense) in male mice. In: D Goldowii/,, D Wahlsten, R Wimer, editors. Techniques for She Genetic Analysis of Brain and Behavior: Focus on the Mouse. Elsevier. New York, 1992; 349-373

37. Jacobs LF, Gaulin SJ, Sherry DP, Hoffmari GH. Evolution of spatial cognition: sex specific patterns of spatial behavior predicted by hippocampal size. Proc Natl Acad Sci USA 1990; 87: 6349-6352

38. Renncr K.I, Bicgon A. Luine VN. Sex differences in longterm gonadectomix.cd rats: monoamine levels and $\left[{ }^{3} \mathrm{H}\right]$ nitoimipraminc binding in brain nuclei. Exp Brain Res 1985; 58: 198-201

39. Carlsson M, Svensson K, Ericksson E, C'lrlsson A. Rat brain serotonin: Biochemical and functional evidence for a sex difference. JNeural Transit'. 1985; 63: 297-3i 3

40. DC Vries GJ. Sex diiTcrences in neurotrimsmiiter systems. Neuwendocrinol 1990; 2: 1-13

41. Vale JR. Ray D. A diallcl analysis of male mouse sex behavior. Behav Genet 1972; 2: 199-209

42. Vale JR. Ray D, Vale CA. The interaction of genotype and exogenous neonatal androgen and estrogen; sex behavior in female mice. On' Pxychr-biol 1973; 6: 319-327

43. Simon NG, LU SF, McKenna SE, Chop, X. Clifford AC. Sexual dimorphism in legulatory systems for aggression. In: M Hang, R Walvlen, C Aron, KL Olsen, editors. The Development of Sex Differences and Similarities in Behavior. Kluwcr, Dordrecht, 1993; 389-408
44. Flam F.Why map Y. Science 1993; 26 1:679

45. Lovell-Badge R, Hacker A. The molecular genetics ofSry and its role in mammalian sex determination. Phil Trans Roy Joe Land B 1995 ; 350: 205-2 14

46. Koopman P, Guhbay J, Vivian N, Goodfellow P, LovellBadge R. Male development of chromosomal ly female mice transgenic for Siy. Nature 1991; 351: 1 17-121

47. Harry J, Koopman P, Brennan FE, Graves JAM, Renfree MB. Widespread expression of the testis determining gene SRY in marsupials. Nat Genet 1995; 11: 347-349

48. Lahr G, Maxson SC, Mayer A, Just W, Pilgrim C, Reiser! I. Transcription of the Y chromosomal gene, Sry, in adult mouse brain. Mol Brain Res 1995; 33: 179-182

49. Clepet C, Schafer AJ, Sinclair AH, Palmer MS, LovellBadge R. Goodfellow PN. The human SRY transcript. Hum Mol Genet \993; 2: 2007-2012

50. Cohen DR, Sinclair AH, McGovern JD. SRY protein enhances transcription of Fos-related antigen 1 promoter construcvs. Proc Natl Acad Sci [/M 1994; 91: 4372-4376

51. Goodman RH. Regulation of neuropeptide gene expression. Anna Rev Neuroscl 1990; 13: 111-127

52. Graves JAM. Mammals that break the rules: Genetics of marsupi'ilsand monotKmes.ArviitftevGetiet 1 996; 30: 233260

53. Colligon J, Sockanathan S, Hacker A, Cohen-Tannondji M, Norris D, Rastan lieial. A comparison of the properties of Sox 3 with Sry and two related genes Sox I and Sox2. Development 1996; 122: 509-520

54. Aguinik AI, Mitchell MJ, Mattel M-G, Borsani G, Avner $\mathrm{PA}$, Lerner JL et al. A novel $\mathrm{X}$ gene with a widely transcribed Y-linked hornologue escapes X-inactivation in mouse and human. Mm? Mo/ Genet 1994; 3: 879-884

55. Scott DM, Ehrmann IE, Ellis PS, Bishop CE, Aguinik AI, Simpson E et al. Identification of a mouse male-specific transplantation antigen, $H-Y$. Nature 1995; 376: 695-698

56. Green field A, Scott D, Pennisi D, Ehrmann I, Ellis P, Cooper L et al. A H-YD ${ }^{\mathrm{h}}$ epitope is encoded by a novel Y chromosome gene. Nal Genet 1966; 14:474-478

57. Fisher EMC, Beer-Romero P, Brown LG, Ridlcy A, McNcil JA, Lawrence JB et al. Homologous ribosomal protein 
genes on the human $\mathrm{X}$ and $\mathrm{Y}$ chromosomes: escape from inactivation and possible implications for Turner syndrome. Cell 1990; 63: 1205-1218

58. Graves JAM. The origin and function of the mammalian $Y$ chromosome and Y-bome genes - an evolving understandmg.BioEsxays 1995; 11: 311--320

59. Koopman P, Ashworth A, Lovell-Badge R. The ZFY gene family in humans and mice. Trends Genet 1991; 7: 132 136

60. ZambrowiczBP, Zimmermann JW, Herendza CJ, Simpson EM, Page DC, Brinster RL et al. Expression of a mouse Zfy-1/ lacZ transgene in the somatic cells of the embryonic gonad and germ cells of the adult testis. Development 1994 1549-1559

61. Lau EC, Mohandas TK, Shapiro LJ, Slavkin HC, Snead ML. Human and mouse amelogenin gene loci are on the sex chromosomes. Genomics 1989; 4: 162-168

62. Salido EC, Yen PH, Kopri vnikar K, Yu L-C, Shapiro LJ. The human enamel protein gene amelogenin is expressed from both the X and Y chromosome. Am J Hum Genet 1992; 50: 303-316

63. Hurst LD. Embryonic growth and the evolution of the mammalian Y chromosome. I. The Y as an attractor of selfish growth factors. Heredity 1994; 73:223-232
64. Hurst LD. Embryonic growth and the evolution of the mammalian Y chromosome. II Suppression of selfish Y-linkcd growth factors may explain the escape from inactivation and rapid evolution of Sry. Heredity 1994; 73:233-243

65. Salo P, Kaariainen H, Page DC, de la Chapelle A. Deletion mapping of stature determinants on the long arm of the $\mathrm{Y}$ chromosome. Hum Genet] 995; 95: 283-286

66. Eicher EM, Washburn LL, Whitney III JB, Morrow KE. Mus poschiavinm $\mathrm{Y}$ chromosome in the $\mathrm{C} 57 \mathrm{BL} / 6 \mathrm{~J}$ murine genome causes sex reversal. Science 1982; 217: 535-537

67. Seaman AJ, Denenberg VH. Sex differences: Distinguishing between genotype and phenotype. Soc Neurosci Abstr 1996:22:2082

68. Jutley JK, Stewart AD. Genetic analysis of the Y chromosome of the mouse: evidence for two loci affecting androgen metabolism. Genet Res 1985; 47: 29-34

69. Reisert I, Pilgrim C. Sexual differentiation of monoaminergic neurons - genetic or epigenetic? Trends Neurosci 1991; 14:468-473

70. Pilgrim C, Hitchison JB. Developmental regulation of sex differences in the brain: Can the role of gonadal steroids be re-defined?Neuroscience 1994; 60: 843-855 